\title{
DEVELOPING SCHOOLOGY-BASED E-LEARNING IN THE DOKKAI CHUKYU LEARNING COURSE
}

\author{
Kadek Eva Krishna Adnyani ${ }^{1}$, Desak Made Sri Mardani ${ }^{2}$ \\ Ni Nyoman Murniasih ${ }^{3}$, I Wayan Adnyana ${ }^{4}$ \\ ${ }^{1,2}$ Prodi Pendidikan Bahasa Jepang, Universitas Pendidikan Ganesha \\ ${ }^{3,4}$ Jurusan Pendidikan Ekonomi S-1, IKIP PGRI BALI \\ e-mail: krishna.adnyani@undiksha.ac.id ${ }^{1}$, desak.mardani@undiksha.ac.id ${ }^{2}$ \\ murniasih@ikippgribali.ac.id ${ }^{3}$, adnyana@ikippgribali.ac.id ${ }^{4}$
}

\begin{abstract}
This research aims to know: (1) what form of schoology appropriate for the dokkai chukyu learning course in Japanese language education department UNDIKSHA is, and (2) how the quality of schoology for the dokkai chukyu learning course in Japanese language education department UNDIKSHA is? This is Research and Development (R\&D) using the development model of ADDIE (Analysis, Design, Development, Implementation, and Evaluation). The data collection methods were observation and questionnaire while the instruments used were in the forms of questionnaire and observation sheets. Assessment of the quality of the product was performed by one expert in material, one expert of learning media, and 10 learners of the dokkai chukyu language course in Japanese language education department. Based on the assessment results of experts of material and media, schoology was determined as very good and could be used with revision. Small groups formative evaluation were conducted using questionnaires to fill out by 10 students of the dokkai chukyu course. The student response on schoology was predominately positive, i.e. agree and strongly agree.
\end{abstract}

Keywords : dokkai chukyu, e-learning, schoology, research and development

\section{INTRODUCTION}

Development of the multimedia-based learning model in Indonesia is still very needed by learners because of lack of learning media suitable for the needs. Some of the constraints are from the aspects of psychology, education, social, economics, and legitimation (still ongoing software piracy), as well as in terms of infrastructure [1].

Japanese language education department of UNDIKSHA is one of the educational institutions that teaches Japanese language education and language skills of which the student output is prepared as teachers of Japanese at the high school level, junior or senior. According to [2] in general, there are four language skills, i.e. listening, speaking, reading, and writing. On Japanese language education department of Undiksha, the course that teaches reading skills is known as dokkai (reading comprehension). Dokkai courses are prerequirement ones. Dokkai chukyu is reading comprehension on the medium level.

Based on the result of the preliminary study in the form of observation, time limitation on the dokkai chukyu course made lecturers did not have chances to conduct minor evaluation or small tests on each lecture. In addition, on the discussion of the material, it was found that some students did not understand well the content of the material due to busy to translate only on the part of the text that was read and translated (in the discussion of the material, a lecturer asked students to read the text in turns and then translated the text). This problem could be solved if students were given extra time outside of the lectures through the elearning model for the better understanding of the material and performed evaluation. 
[3] mentioned that the use of elearning is basically the most effective way in education because learning is mostly online-based, yet the use of e-learning requires careful consideration, so that it provides benefits for the improvement of the quality of the results of the study and the expected education quality, and principally is inseparable from everyday life and selfinteractive learning for maximum learning.

[4] mentioned that regular and explicit training in foreign language learning strategies, adapted to a blended-learning model can help students improve their learning of the target language. Students learn much more effectively in a blended learning context The use of a blended learning approach enriches the design and implementation of communicative tasks.

Blended learning, also known as hybrid learning, has been a buzz word in higher education over the past two decades. However, there is not much consensus over its definition [5]. Blended learning is a form of learning that combines traditional full-time form of teaching with modern forms of elearning, increasing the advantages and offsetting the disadvantages of each [6].

[7] mentioned that supporting the teaching process with appropriate e-learning techniques and web tools influences positively the development of language skills, and consequently favours the development of the key competence of communicating in foreign languages.

It is especially important that students understand how to use the technology before they engage in the activities. It is also important to provide technical assistance throughout the course and activities. When planning to implement a mobile learning activity, teachers should schedule additional time to provide technical support and assistance to those students struggling with their mobile tools [8]

The use of mobile devices is fast becoming ubiquitous, but we still have much to learn in the new domain of mobile assisted language learning. There is potentially a chasm between those interested in the potential of mobile language learning, including developers with insufficient knowledge of pedagogy, and language teachers who know about pedagogy, but have little interest in mobile learning [9].

Schoology is an online platform that combines social media and electronic classroom management. Schoology provides features such as the list of attendance, tests and quizzes, and homework. These features are designed to use social media in facilitating the interaction of teaching and learning activities. Schoology is the work of three alumni of the 23 year old from Washington University in St. Louis that are; Jeremy Friedman, Ryan Hwang, and Tim Trinidad. Friedman, one of the founders of Schoology, explains that students want to use more of collaborative spaces and the teachers want to make use of the desire of the students for the process of teaching and learning. Therefore, Friedman sees the opportunity to create interactive and social relations between two such interests [10].

Research on the languages elearning, blended learning and schoology, has already been done before and examined using various approaches. [11] investigated the needs and opportunities for high school math teachers pertaining to the adoption of Schoology, a learning management system (LMS). Data was gathered from 98 students, 13 teachers, 24 parents/families and 8 technology integration experts in an effort to gain a multitude of perspectives relating to Schoology use at the high school level. Five needs and opportunities had been identified from this research. First, students need to be taught how to use Schoology. Second, teachers need to be trained to use Schoology. Third, parents need to be involved in the integration process. Fourth, schoology offers many opportunities to students, teachers and parents. Fifth, schoology allows a teacher to share resources and create educational experiences in a manner that has never been seen before.

[12] investigated (1) the differences in learning outcome between Blended Learning based on Schoology and ProblemBased Learning, (2) the differences in learning outcome between students with prior knowledge of high, medium, and low, 
and (3) the interaction between Blended Learning based on Schoology and prior knowledge to the learning outcome. This type research was quasi-experimental with research subjects as many as 64 students. The results of this study revealed that: (1) there was significant differences in learning outcome between Blended Learning based on Schoology and Problem-Based Learning, (2) there were significant differences in learning outcome between students with high, medium, and low prior knowledge, and (3) there was no interaction between Blended Learning based on Schoology and prior knowledge to the learning outcome).

[13] reported how Schoology mlearning platform facilitated the exercise of learner autonomy in an EAP class at an Indonesian higher education. The findings suggested that Schoology m-learning platform helped the students to exercise autonomy in EAP learning. The students exercised their control over learning management, cognitive process, and selection of learning materials.

[14] examined the potential and limitation of SkELL in the language classroom for Japanese students who have almost no online experience in educational settings. Sketch Engine for Language Learning (SkELL) is a relatively new webbased tool for language learning. The findings indicate that using selected example sentences from SkELL to help students imagine contextual situations is one way for teachers to achieve specifc communicative teaching goals. Students also said that using mobile phones inside as well as outside the classroom is one way for them to fully beneft from SkELL.

[15] identified whether the use of Web 2.0 applications is more effective in teaching Japanese language compared to the traditional method of using the textbook only. This study focused on students taking Japanese language course SKVA2723 at the School of Language Studies and Linguistics in the National University of Malaysia (UKM) from February to December 2012 for 2 semesters. A total of one teacher and 55 students were involved in this study. the findings showed that the group of students who were exposed to the Web 2.0 applications showed more motivation, enthusiasm, excitement and higher scores compared to the group that was not exposed to the applications. The implication from this study is that the use of the application can be applied to more complex kanji orthography, particularly those that require more than 10 strokes

[16] conducted a research to (1) design a Schoology-based blended learning media for Basic Physics I course (2) describe the validity of the product, (3) describe the products effectiveness in enhancing students conceptual understanding and problem solving skills, and (4) describe students responses towards the media and blended learning model.

The development procedures employed were ADDIE model. The two validity experts results showed that the content aspect and construct aspect were very good and good, respectively. The results from classroom implementation revealed the effectiveness of the product in enhancing students conceptual understanding and problem solving skills. Students responses towards the products utility, attractiveness, and easiness as blended learning media were also positive. The conclusion was that the media was valid and effective as blended learning media of Basic Physics I course.

[17] describe the design of the elearning portal based Schoology development in social studies class VIII SMP Negeri 1 Banjarangkan school year $2014 / 2015$, the quality of e-learning portal based Schoology, and determining the effectiveness of the portal based Schoology e-learning use. The results of the expert evaluation of the subjects teacher were in good qualifications (88\%), learning design expert evaluation results in the excellent qualifications (90\%), the evaluation results of learning media expert in the excellent qualifications $(92 \%)$, individual test results were in excellent qualifications (92\%), small groups of test results in the good qualifications $(87,8 \%)$, and the results of field tests in the excellent qualifications $(95,1 \%)$. Pre-test average value $(54.33)$ is smaller than the value of post-test (80.33). 
Based on inferential statistical analysis (ttest), there is a significant difference between the results of social studies before and after using the e-learning portal based Schoology. It can be concluded that elearning portal based Schoology is effective to improve learning outcomes in social studies of student class VIII SMP Negeri 1 Banjarangkan school year 2014/2015.

Based on the results of the needs analysis and the lack of number of students or lecturers who do research on the development of Undiksha environment, it is important to do research on the learning model of the development of e-learning in the dokkai chukyu course. it is expected that with the use of technology in the learning process, students could access information material and take evaluation more practically and effectively.

In line with the background described, the problem can be formulated as follows:

1. What are forms of schoology appropriate for the dokkai chukyu subject in the Japanese language education in Undiksha?

2. How is the quality of schoology developed in the courses in the dokkai chukyu course of Japanese language department in Undiksha?.

\section{METHOD}

The development model used in the development was the ADDIE model. This model was chosen because it is developed in a systematic and theoretical foundation based on the instructional design. The following is the picture of the stages in the ADDIE model;

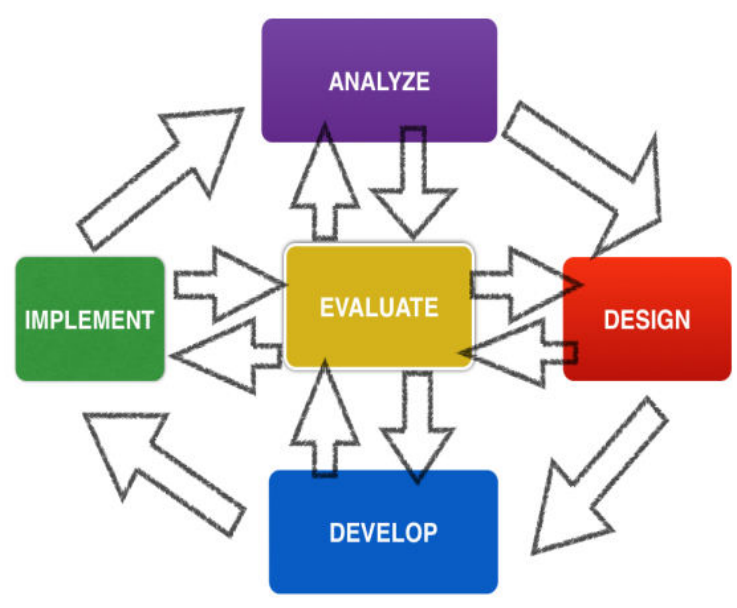

Figure 1. Stages in the ADDIE Model

[18] mentioned that the ADDIE model has five steps or stages that are easily understood and implemented to develop products such as the textbook, learning modules, videos, multimedia learning, and more. The stages in the ADDIE model could be described as follows;

1. Analysis: it includes the analysis of the competencies required by the students, the analysis of characteristic of students on their learning capacity, knowledge, skills, attitudes and other related aspects, as well as conducting analysis on the material in accordance with the demands of competence. In this study, this stage was performed through disseminating a questionnaire to all participants of the dokkai chukyu course to see whether the development of the model was really needed in learning. In addition, observations were also carried out during the class.

2. Design: it is performed with terms of reference as follows; for whom the instruction is designed, kinds of ability are wanted to be studied, how learning materials could be studied properly, and how to determine the level of mastery of the lessons are already achieved. In this study, the stage of design was performed by creating a blue print material and the quiz would be inputted into schoology.

3. Development: it is the activity to translate design specifications into a physical form in order to produce a 
prototype of the product development. The development stage of this study was conducted through inputting the material and quizzes to schoology. The assessment by material and media experts was performed once the material and quizes were inputted into schoology.

4. Implementation: the results of development are applied in learning to know the effects on the quality of learning that includes effectiveness, interestingness, and the efficiency of learning. In this study, the stage of implementation was accomplished by using the model on the teaching and learning of the dokkai chukyu course.

5. Evaluation: it is conduct through evaluation that includes formative and summative evaluations. In the developmental research, formative evaluation is generally used because this type of evaluation is related to stages of developmental research to improve the product developed. In this study, small groups formative evaluation were done by disseminating a questionnaire to 10 participants of the dokkai chukyu course.

\section{RESULTS AND DISCUSSION}

This research was carried out in stages which are generally divided into five phases in accordance with the stages in the ADDIE model i.e. the analysis, design, development, implementation, and evaluation.

1. Analysis: at the stage of the analysis, research was done through the observation in the classroom.

Based on the observation results, it is noted that:

1) Learning Media used in the dokkai chukyu course was just a textbook titled Minna no nihongo Chukyuu II: Chukyuu de yomeru topikku 25.

2) Interactive multimedia not available

3) Time limitations on the process of teaching and learning made lecturers did not have time to hold quizzes and explained in more depth on some of the students who did not understand the material well yet.
4) There was a network connection to the internet and all students had laptops as well as being able to use the internet.

2. Design: at this stage, material and tasks were formulated to be inputted on the system.

3. Development: in this study, the stage of development was done by inputting the material and quizzes to schoology. The following is the display of schoology:

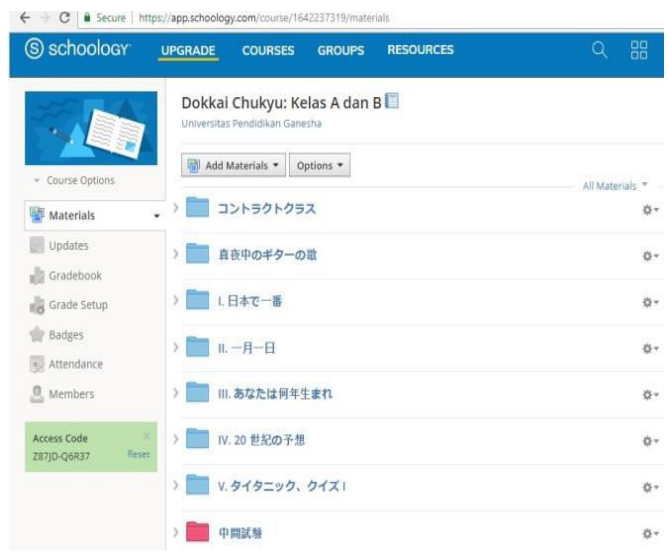

Figure 2. The Display of the Materials

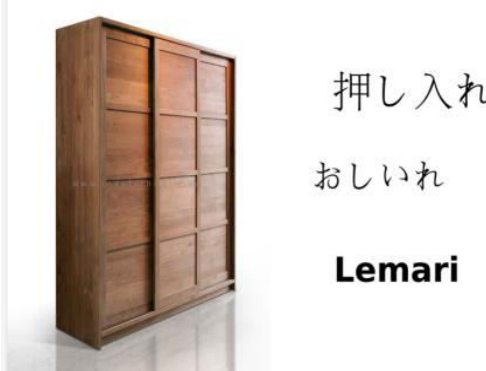

Figure 3. Example of the Material

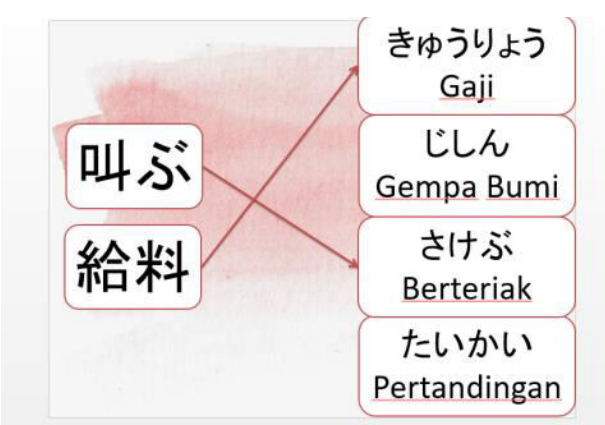

Figure 4. Example of the Quiz 


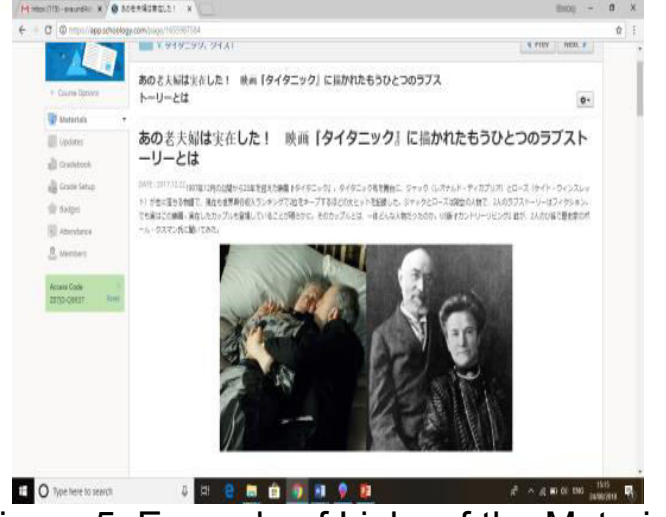

Figure 5. Example of Links of the Material from the Website

The assessment by the material and media experts was performed once the material and quizzes were finished and inputted into schoology. Based on the results of assessment by material and media experts, it is obtained the following results.

1) Based on the validation by the expert of material, it is obtained the following results Generally, schoology is said to be very good and could be used without revision.

Table 1. The Material Expert Judgement

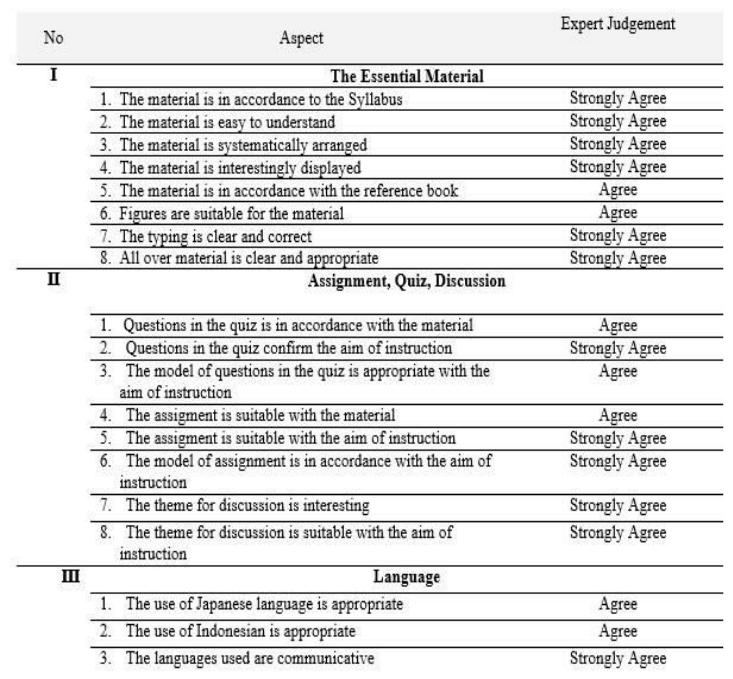

2) Based on the Validation of the expert in media, it is obtain the following results:

Table 2. The Media Expert Judgement

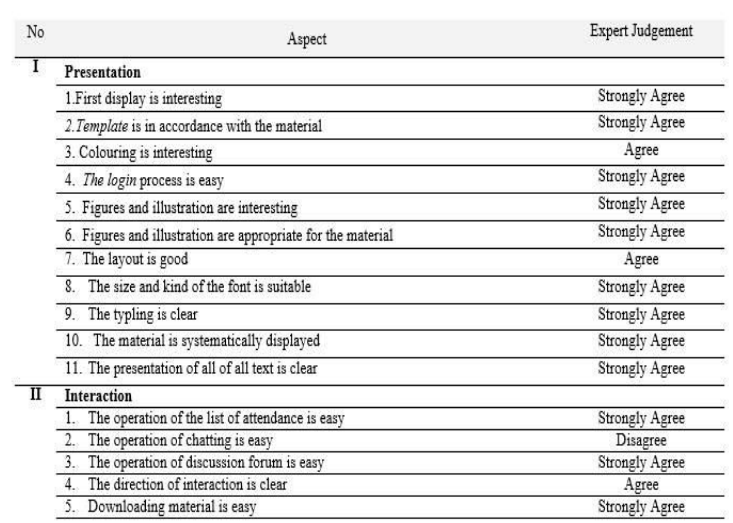

Suggestions from the expert of media are as follow:

1. The use of "chatting" is inappropriate, use discussion (discussion forum) instead

2. There should be description on the folder of topics of the meeting

In General, the schoology is evaluated as well and can be used without revision.

The results of the assessment of experts are later calculated and converted using the following formula from [19].

Table 3. Conversion Formulas

\begin{tabular}{lc}
\multicolumn{1}{c}{ Score } & Criteria \\
\hline $\mathrm{X} \geq \mathrm{Mi}+1.5 \mathrm{Sdi}$ & Very Good \\
\hline $\mathrm{Mi}+0.5 \mathrm{Sdi} \leq \mathrm{X}$ & Good \\
$\leq \mathrm{Mi}+1.5 \mathrm{Sdi}$ & \\
\hline $\mathrm{Mi}-0.5 \mathrm{Sdi} \leq \mathrm{X}$ & Fair \\
$\leq \mathrm{Mi}+0.5 \mathrm{Sdi}$ & \\
\hline $\mathrm{Mi}-1.5 \mathrm{Sdi} \leq \mathrm{X}$ & Less Good \\
$\leq \mathrm{Mi}+0.5 \mathrm{Sdi}$ & \\
\hline $\mathrm{X}<\mathrm{Mi}-1.5 \mathrm{Sdi}$ & $\mathrm{Bad}$
\end{tabular}

Note:

$\mathrm{Mi}=1 / 2$ (Score Max + Score Min)

$\mathrm{Sdi}=1 / 3(\mathrm{Mi})$

$\mathrm{Mi}=$ the Ideal Mean

Sdi $=$ the Standard of Deviation

$X=$ The Score of the teacher.

The data analysis is explained as follow

Table 4. Determining $\mathrm{X}, \mathrm{Mi}$, and Sdi 


\begin{tabular}{|c|c|c|c|}
\hline No. & Note & $\begin{array}{c}\text { The } \\
\text { Material } \\
\text { Expert }\end{array}$ & $\begin{array}{c}\text { The Media } \\
\text { Expert }\end{array}$ \\
\hline 1 & $\mathrm{X}$ & 69 & 78 \\
\hline \multirow[t]{9}{*}{2} & \multirow[t]{9}{*}{$\mathrm{Mi}$} & Formula: & Formula \\
\hline & & $\mathrm{M} i=\quad 1 / 2$ & $\mathrm{M} i=$ \\
\hline & & (Score & (Score Max \\
\hline & & Max & + Score Min) \\
\hline & & Score & \\
\hline & & Min) & \\
\hline & & $1 / 2(76+19)$ & $1 / 2(84+21)=$ \\
\hline & & $=1 / 2(95)=$ & $1 / 2 \quad(105)=$ \\
\hline & & 47,5 & 52,5 \\
\hline \multirow[t]{3}{*}{3} & \multirow[t]{3}{*}{ Sdi } & $\begin{array}{l}\text { Formula: } \\
1 / 3(\mathrm{M} i)\end{array}$ & $\begin{array}{l}\text { Formula: } 1 / 3 \\
(\mathrm{M} i)\end{array}$ \\
\hline & & $1 / 3 \quad(47,5)$ & $1 / 3(52,5)=$ \\
\hline & & $=15,83$ & 17,5 \\
\hline
\end{tabular}

After finding $\mathrm{X}, \mathrm{Mi}$, and Sdi, $\mathrm{X}$ is then converted in accordance with Table 4. and the results are as follow:

$$
\begin{aligned}
& \text { Material Expert : } \\
& X \geq \mathrm{Mi}+1 / 2 \text { Sdi } \\
& 69 \geq 47,5+7,9 \\
& 69 \geq 55,4 \\
& \text { (Very Good) } \\
& \\
& \text { Media Expert } \\
& X \geq \mathrm{Mi}+1 / 2 \text { Sdi } \\
& 78 \geq 52,5+8,75 \\
& 78 \geq 61,25 \\
& \text { (Very Good) }
\end{aligned}
$$

Based on the results of expert validation it is found that the quality of the developed application is categorized as Very Good. Although there are some weaknesses that are fixed, the product developed in this research is expected to help Japanese language learners in dokkai chukyu course.

4. Implementation: in this study, the stage of implementation was done by using schoology on teaching and learning of the dokkai chukyu course.

5. Evaluation: in this study, small groups formative evaluation carried out using questionnaires to 10 participants of the dokkai chukyu course. The questionnaire was used to find out the students' response toward schoology.

After the determining the indicators, the next step was making a grid that would be used as a guide in making questions on the question form. There are four indicators in the questionnaire, namely user interface, usage, material, and user satisfaction. Furthermore, the results of student responses will be outlined in Figures 6 -9.

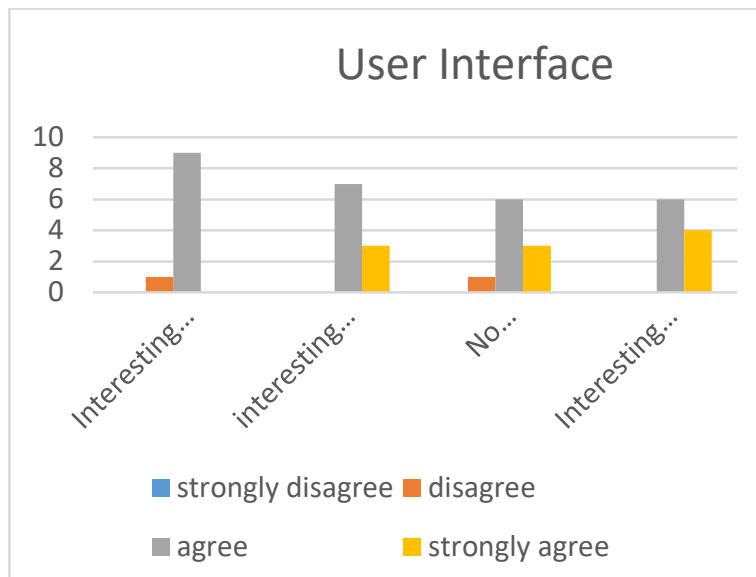

Figure 6. The User Interface of Schoology

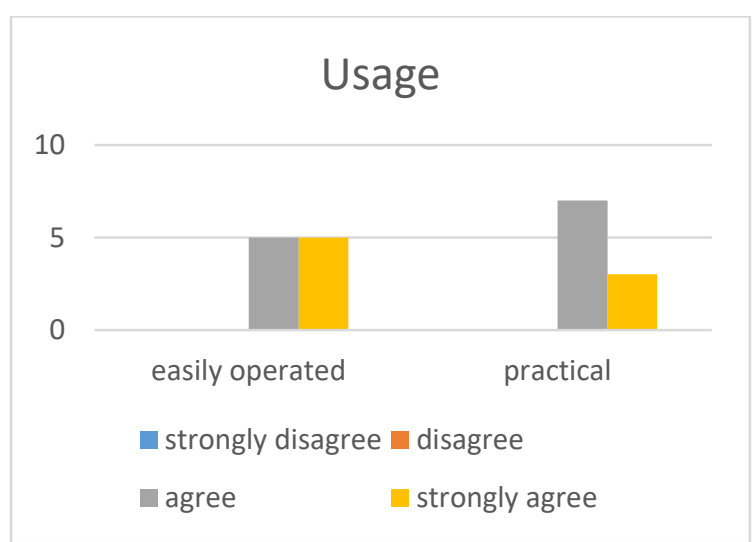

Figure 7. The Usage of Schoology

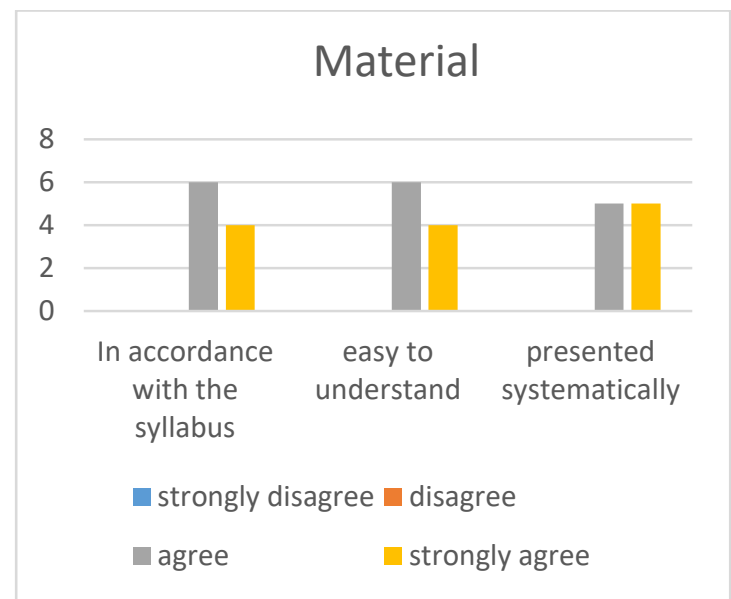

Figure 8. The Material of Schoology 


\section{User Satisfaction}

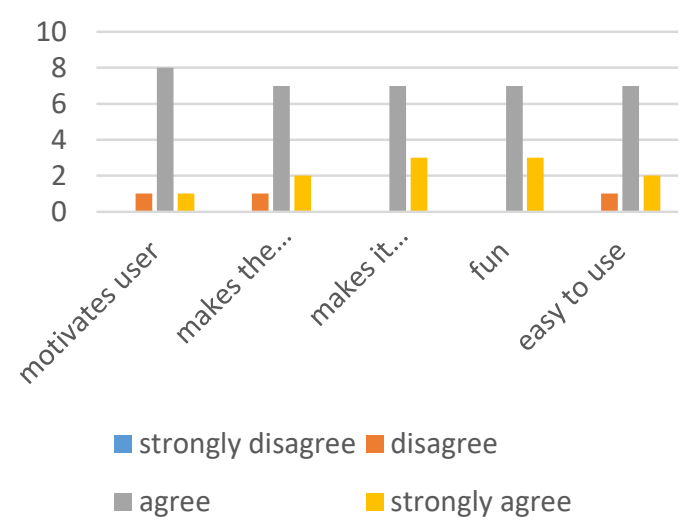

Figure 9. The User Satisfaction on Schoology

The students' responses are dominated with positive ones, i.e. agree and strongly agree. However, there are statements with the responses of less agree. They are on statements in the display (an interesting display and interesting illustration) and in the user satisfaction (Motivating and users like to use it). Nevertheless, the particular responses are very rare. In addition, the responses of "disagree" does not appear on all of the statements.

There are a few comments and suggestions for improvement. They are as follow.

1. The application is already very good both in terms of the material and the width of knowledge.

2. It looks simple and it would be more interesting if it is added with Japanese nuance. The material is already nice and innovative, making students more easily study.

3. Very practical, which required only a laptop/smartphone and an internet access. Also save money because it does not need to copy the book. If it could be accessed offline, it would definitely be better because the $\mathrm{Wi}-\mathrm{Fi}$ signal in campus is difficult to access.

4. The slide background images and colours should be changed into interesting ones so that learning becomes more enjoyable.
Both positive and negative comments were used to revise the product. Test results and students' responses as the users generally indicate that the quality of schoology is very good, having interesting display, easy to use, appropriate in terms of the material syllabus, and able to help understanding the material. This is in accordance with the theory of Desrianti, et al (2013) which mentioned that the use of elearning is basically the most effective way in education and the theory of Kalamarz (2014) which mentioned that supporting the teaching process with appropriate elearning techniques and web tools influences positively the development of language skills.

\section{CONCLUSION}

I argued at the beginning of this article that it is important to do research on the learning model of the development of elearning in the dokkai chukyu course. It is expected that with the use of technology in the learning process, students could access information material and take evaluation more practically and effectively

The findings that I have presented suggest that based on the assessment results of experts of material and media, schoology was determined as very good and could be used with revision. The student response on schoology was predominately positive, i.e. agree and strongly agree.

This is important for Japanese language students and teachers because it shows how schoology address the "anywhere any device" aspect of flexible learning because assignments, dicussions, assesments are all available on the mobile app.

As a result of conducting this research, I propose that there are several benefits of using schoology in the learning process, such as : 1) it reduces learning cost, 2) it provides unlimited access to learning material, and 3) it easily tracks learner progress and performace.

It would be fruitful to pursue further research about the impact of blended learning by using LMS (Learning 
Management System) in the dokkai chukyu course in order to investigating whether or not there was a significant difference in reading comprehension competency between students who learnt in blended learning environment and those who learnt in conventional environment.

\section{REFERENCES}

[1] A. T. Wijaya. (2011, May). Media Pembelajaran Huruf Hiragana dan Katakana untuk Pemula Berbasis Multimedia Menggunakan Macromedia Flash. [Online]. Available: https://eprints.uny.ac.id/19497/

[2] W. Meidani. (2006). Peranan Mata Kuliah Mengarang (Sakubun) dalam Pembelajaran Bahasa Jepang. [Online]. Available:

https://docplayer.info/32274546Peranan-mata-kuliah-mengarangsakubun-dalam-pembelajaran-bahasajepang-m-a-k-a-l-a-h-oleh-wawanmeidani.html

[3] D. I. Desrianti, U. Rahardja, and R. Rinie. (2014, May). "llearning Metode Belajar Efektif untuk Sekolah Tinggi," CCIT Journal [Online]. Vol. 7 no. 3. pp $308 \quad-334 . \quad$ Available: http://raharja.ac.id/raharja_file/file_jurnal /file/7030114.pdf

[4] A.F. Ferreira, J. G. Salinas, and S. Morales. "Using a task-based approach for supporting a blended learning model for English as a foreign language," International Journal of ComputerAssisted Language Learning and Teaching, 4(1), pp. 44-62, JanuaryMarch. 2014.

[5] M. Alizadeh, P. Mehran, I. Koguchi. Evaluating a blended course for Japanese learners of English: why Quality Matters. Int J Educ Technol High Educ, Vol. 16 No. 6 pp 1-21. Mar. 2019.

[6] I. Rymanova, N. Baryshnikova and A. Grishaeva. "E-course Based on the LMS Moodle for English Language Teaching: Development and Implementation of Results," Procedia Social and Behavioral Sciences 206 pp. 236 - 240. Oct. 2015.
[7] R. Kalamarz. "Blending foreign language learning with key competences. Does e-learning do the trick?," Int. J. Cont. Engineering Education and Life-Long Learning, Vol. 24, No. 1, pp. 77 -95, Feb. 2014.

[8] K. Daesang, D. Ruecker, and D. J. Kim. "Mobile Assisted Language Learning Experiences," International Journal of Mobile and Blended Learning, vol. 9 no. 1 pp. 49-66. 2017.

[9] P. Sweeney and C. Moore. "Mobile Apps for Learning Vocabulary: Categories, Evaluation and Design Criteria for Teachers and Developers," International Journal of ComputerAssisted Language Learning and Teaching,2(4), 1-16, October-December 2012.

[10] G. Moran. (2010, Sept). The Rise of Virtual Classroom. [Online]. Available: https://www.entrepreneur.com/article/21 7320

[11] D. Schlager. (2016, Aug). Schoology: The Adoption of a Learning Management System. [Online]. Available:

https://sophia.stkate.edu/maed/191

[12] V. T. Irawan, E. Sutadji, and Widiyanti. (2017, Jan). "Blended learning based on schoology: Effort of improvement learning outcome and practicum chance in vocational high school", Journal Cogent Education [Online]. Vol 4, 2017 Issue 1, pp. 1-10. Available

https://www.tandfonline.com/doi/full/10.1 080/2331186X.2017.1282031

[13] P. Ardi. "Promoting Learner Autonomy through Schoology MLearning Platform in an EAP Class at an Indonesian University," Teaching English with Technology, vol. 17 no. 2 pp. 55-76. 2017.

[14] Y. Hirata and Y. Hirata. "Applying 'Sketch Engine for Language Learning' in the Japanese English classroom," Journal of Computing in Higher Education, Vol. 31 Issue 2, pp. 233-248. August. 2019.

[15] M. Shabudin, A. Aisyah, S. Darus, and N. Mimiko. "Development of Teaching Materials and Utilization of 
Web 2.0 in Japanese Language Teaching and Learning," ProcediaSocial and Behavioral Sciences, 118, pp. 433-441. Mar. 2014.

[16] W. Suana, N. Mahartana, I. D. P. Nyeneng. (2017, Apr). "Design and Implementation of Schoology-Based Blended Learning Media for Basic Physics I Course". [Online]. Jurnal Pendidikan IPA Indonesia Vol 6, No 1 pp. $\quad 170 \quad-178 . \quad$ Available: https://journal.unnes.ac.id/nju/index.php /jpii/article/view/8648/6318

[17] K. F. Apriyana, N. Wirya, and D. P. Parmiti. (2015, Jan). "Pengembangan Portal E-Learning Berbasis Schoology pada Mata Pelajaran IPS Kelas VIII di SMPN 1 Banjarangkan," E-Journal Edutech Universitas Pendidikan Ganesha Jurusan Teknologi Pendidikan. [Online]. Vol: 3 No: 1 Tahun 2015. Available: https://ejournal.undiksha.ac.id/index.php /JEU/article/view/5603

[18] M. Tegeh, I. N. Jampel, and K. Pudjawan. Model Penelitian Pengembangan. Yogyakarta: Graha IImu, 2014.

[19] W. Nurkancana and Sunartana. Evaluasi Hasil Belajar. Surabaya: Usaha Nasional, 1992. 